\title{
Pengaruh Kadar Albumin Serum terhadap Penyembuhan Luka pada Pasien Pascaoperasi Laparotomi dan Lumbotomi di RSD dr. Soebandi Jember
}

\section{(Albumin Serum's Effect on Wound Healing in Patients Postoperative Laparotomy and Lumbotomy at dr. Soebandi Hospital Jember)}

\author{
Meytika Fauziah Sugiartanti, Duriyanto Oesman, Ulfa Elfiah \\ Fakultas Kedokteran, Universitas Jember \\ Jl. Kalimantan 37, Jember 68121 \\ email: meytikafs@gmail.com
}

\begin{abstract}
Wound healing need protein as basis for the formation of collagen network. The important component of protein is albumin. The aim of this study was to investigate albumin serum's effect on wound healing in patients postoperative laparotomy and lumbotomy at dr. Soebandi Hospital Jember. The method of study was analytic observational with cross sectional design. Total samples in this study were 9 samples. The results showed that the higher albumis, the faster wound healing. Data analysis using bivariate analyzing Spearman's Rho test showed that the significance $(p)=0.011$ and correlation coefficients $(r)=0.791$. Thus, it can be concluded that there were a strong albumin serum's effect of wound healing in patients postoperative laparotomy and lumbotomy at RSD dr. Soebandi Jember.
\end{abstract}

Keywords: Wound healing, Protein, Albumin.

\begin{abstract}
Abstrak
Proses penyembuhan luka memerlukan protein sebagai dasar terbentuknya jaringan kolagen. Komponen penting dari protein adalah albumin. Tujuan penelitian ini adalah untuk membuktikan adanya pengaruh kadar albumin serum terhadap penyembuhan luka pada pasien pascaoperasi laparotomi dan lumbotomi di RSD dr. Soebandi Jember. Penelitian ini menggunakan metode analitik observasional dengan pendekatan cross sectional. Jumlah sampel dalam penelitian ini sebanyak 9 sampel. Hasil penelitian ini menunjukkan bahwa semakin tinggi albumin maka semakin cepat penyembuhan luka. Analisis data dilakukan dengan analisis bivariat menggunakan uji Spearman's Rho yang menunjukkan signifikansi $(p)=0,011$ dengan koefisien korelasi $(r)=0,791$. Dengan demikian dapat disimpulkan bahwa terdapat pengaruh yang kuat antara kadar albumin serum dengan penyembuhan luka pada pasien pascaoperasi laparotomi dan lumbotomi di RSD dr. Soebandi Jember.
\end{abstract}

Kata kunci: Penyembuhan luka, Protein, Albumin.

\section{Pendahuluan}

Jenis luka yang dihasilkan dari tindakan bedah membutuhkan proses penyembuhan [1]. Proses penyembuhan luka ini memerlukan protein sebagai dasar terbentuknya jaringan kolagen, sedangkan komponen penting dari protein adalah albumin. Albumin dapat digunakan sebagai prediktor terbaik penyembuhan pasien [2]. Albumin merupakan 
protein plasma yang paling banyak dalam tubuh manusia, yaitu sekitar $55-60 \%$ dari protein serum yang terukur [3].

Fase penyembuhan luka dapat terbagi menjadi fase inflamasi, proliferasi, dan maturasi [4] Laparotomi adalah tindakan insisi pembedahan melalui dinding perut atau peritoneum [5]. Lumbotomi merupakan insisi pada bagian posterior (retroperitoneal) dan secara anatomi langsung menuju ginjal dan saluran kemih bagian atas [6].

Berdasarkan data dari Instalasi Bedah Sentral (IBS) RSD dr. Soebandi Jember, prevalensi pasien yang menjalani operasi laparotomi dan lumbotomi elektif di RSD dr. Soebandi pada tahun 2012 sebanyak 343 pasien, tahun 2013 sebanyak 465, dan terus meningkat pada tahun 2014 yaitu sebanyak 491 pasien. Data terbaru pada bulan Agustus 2015 jumlah pasien yang menjalani operasi laparotomi dan lumbotomi elektif sebanyak 27 pasien.

Tujuan penelitian ini adalah membuktikan adanya pengaruh kadar albumin serum terhadap penyembuhan luka pada pasien pascaoperasi laparotomi dan lumbotomi di RSD dr. Soebandi Jember.

\section{Metode Penelitian}

Jenis penelitian ini adalah penelitian analitik analitik observasional dengan pendekatan cross sectional. Penelitian ini dilakukan di ruang rawat inap dan Poli Bedah RSD dr. Soebandi Jember pada bulan November 2015. Penelitian telah mendapat persetujuan etik dari Komisi Etik Penelitian Fakultas Kedokteran Universitas Jember. Besar sampel pada penelitian ini adalah 9 sampel dengan teknik pengambilan sampel menggunakan total sampling. Kriteria inklusi dalam penelitian ini yaitu pasien bersedia menjadi responden, pasien mengikuti prosedur penelitian sampai dengan tahap akhir, pasien dapat bekerjasama dengan peneliti (kooperatif), pasien yang dapat diikuti antara hari ke-1 sampai dengan 5 dan hari ke- 6 sampai dengan ke-11 postoperasi, dan pasien yang memiliki hasil laboratorium nilai albumin preoperasi di rekam medis. Sedangkan kriteria eksklusi dalam penelitian ini yaitu pasien yang dari awal sudah diketahui luka kotor atau infeksi (dirty or infected wounds), pasien anak-anak, dan pasien yang mendapat intervensi albumin.
Instrumen yang digunakan dalam penelitian ini adalah lembar penilaian luka secara klinis pada Tabel 1 dan 2.

Tabel 1. Penilaian luka sembuh secara klinis

\begin{tabular}{|c|c|}
\hline & $\begin{array}{l}\text { Luka dikatakan sembuh } \\
\text { secara klinis }\end{array}$ \\
\hline $\begin{array}{c}\text { hari ke-1 } \\
\text { sampai } \\
\text { dengan } \\
\text { ke-5 }\end{array}$ & $\begin{array}{ll}\cdot & \text { kemerahan (rubor) } \\
& \text { suhu teraba hangat di } \\
& \text { sekitar luka (kalor) } \\
& \text { rasa nyeri (dolor) } \\
& \text { pembengkakan (oedem) }\end{array}$ \\
\hline $\begin{array}{c}\text { Hari ke-6 } \\
\text { sampai } \\
\text { dengan } \\
\text { ke-11 }\end{array}$ & $\begin{array}{l}\text { luka mulai merapat, } \\
\text { tegangan pada luka } \\
\text { berkurang, oedem } \\
\text { berkurang } \\
\text { warna kemerahan pada } \\
\text { luka berkurang } \\
\text { suhu teraba normal di } \\
\text { sekitar luka } \\
\text { nyeri pada luka berkurang } \\
\text { luka terasa gatal } \\
\text { luka sudah menutup }\end{array}$ \\
\hline
\end{tabular}

Tabel 2. Penilaian luka sembuh tertunda secara klinis

Luka dikatakan sembuh tertunda secara klinis

- terdapat eksudat dan tanda-tanda infeksi

- terdapat diskontinuitas jaringan

- luka berbau

- luka basah

- jahitan masih terbuka

Uji statistik yang digunakan adalah uji normalitas Shapiro Wilk dan uji korelasi Spearman's Rho karena jenis data variabel yang dinilai adalah kategorik.

\section{Hasil Penelitian}

Distribusi Sampel Berdasarkan Kadar Albumin Serum

Kadar albumin serum dalam penelitian ini dikelompokkan menjadi tiga yaitu $<3,5 \mathrm{~g} / \mathrm{dL}$, $3,5-5,5 \mathrm{~g} / \mathrm{dL}$, dan $>5,5 \mathrm{~g} / \mathrm{dL}$. \%. Kadar albumin normal yaitu antara 3,5-5,5 $\mathrm{g} / \mathrm{dL}$. Berdasarkan Tabel 3 dapat diketahui bahwa sampel 
terbanyak dengan kadar albumin $<3,5 \mathrm{~g} / \mathrm{dL}$ sebanyak 6 sampel dan jumlah sampel dengan kadar albumin 3,5-5,5 g/dL sebanyak 3 sampel.

Tabel 3. Distribusi kadar albumin serum sampel

\begin{tabular}{lc}
\hline Kadar albumin serum & Jumlah \\
\hline$<3,5 \mathrm{~g} / \mathrm{dL}$ & 6 \\
$3,5-5,5 \mathrm{~g} / \mathrm{dL}$ & 3 \\
$>5,5 \mathrm{~g} / \mathrm{dL}$ & 0 \\
Jumlah & 9 \\
\hline
\end{tabular}

Distribusi Sampel Berdasarkan Penilaian Luka

Berdasarkan Tabel 4 dapat diketahui bahwa jumlah sampel dengan luka sembuh yaitu sebanyak 4 sampel dan luka sembuh tertunda sebesar 5 sampel.

Tabel 4. Distribusi penilaian sampel

\begin{tabular}{lc}
\hline Penilaian luka & Jumlah \\
\hline Sembuh & 4 \\
Sembuh tertunda & 5 \\
Jumalah & 9 \\
\hline
\end{tabular}

Tabulasi silang pengaruh kadar albumin serum dengan penyembuhan luka pascaoperasi laparotomi dan lumbotomi

Tabulasi Tabulasi silang pengaruh kadar albumin serum dengan penyembuhan luka pascaoperasi laparotomi dan lumbotomi dapat dilihat pada Tabel 5 di bawah ini:

Tabel 5. Tabulasi pengaruh kadar albumin serum dengan penyembuhan luka

\begin{tabular}{|c|c|c|c|}
\hline \multirow[b]{2}{*}{ Albumin } & \multicolumn{2}{|c|}{ Penilaian Luka } & \multirow[b]{2}{*}{ Jumlah } \\
\hline & Sembuh & $\begin{array}{l}\text { Sembuh } \\
\text { tertunda }\end{array}$ & \\
\hline$<3,5 \mathrm{~g} / \mathrm{dL}$ & 1 & 5 & 6 \\
\hline $3,5-5,5 \mathrm{~g} / \mathrm{dL}$ & 3 & 0 & 3 \\
\hline Jumlah & 4 & 5 & 9 \\
\hline
\end{tabular}

Berdasarkan Tabel 5 dapat diketahui bahwa sampel dengan albumin $<3,5 \mathrm{~g} / \mathrm{dL}$ yang dinyatakan luka sembuh tertunda sebesar lima sampel dan dinyatakan luka sembuh sebesar satu sampel. Jumlah sampel dengan albumin 3,5-5,5 g/dL dengan luka sembuh yaitu tiga sampel. Secara keseluruhan, dari sembilan sampel, lima di antaranya, luka pascaoperasi mengalami sembuh tertunda dan empat lainnya dinyatakan luka sembuh.

\section{Uji Normalitas}

Uji normalitas yang dipilih dalam penelitian ini adalah uji Shapiro Wilk. Pada uji ini menunjukkan hasil signifikansi $(p)=0,000$, dimana $p<0,05$ maka data dalam penelitian ini terdistribusi tidak normal.

\section{Uji Spearman's Rho}

Hasil uji korelasi Spearman Rho disajikan dalam Tabel 6.

Tabel 6. Hasil uji Spearman Rho

\begin{tabular}{cc}
\hline & Kadar albumin serum \\
\hline $\begin{array}{c}\text { Penyembuhan } \\
\text { Luka }\end{array}$ & Koefisien korelasi $(r) 0.791$ \\
& Signifikansi (p) 0.011 \\
Jumlah data $(n) 9$
\end{tabular}

Berdasarkan tabel di atas, variabel yang diuji dalam penelitian ini memiliki signifikansi $(p)$ sebesar 0,011 artinya terdapat hubungan antara kadar albumin serum dengan penyembuhan luka pada pasien pascaoperasi laparotomi dan lumbotomi. Kekuatan dan arah korelasi dapat diketahui dengan melihat koefisien korelasi ( $r$ ). Nilai $r$ dalam penelitian ini adalah 0,791 yang menunjukkan bahwa kekuatan korelasi antara kadar albumin serum dengan penyembuhan luka adalah kuat. Arah korelasi positif artinya semakin tinggi albumin maka semakin cepat penyembuhan luka pada pasien pascaoperasi laparotomi dan lumbotomi.

\section{Pembahasan}

Pada penelitian ini didapatkan sampel sebesar sembilan sampel. Pada Tabel 5 dapat diketahui bahwa sampel dengan albumin $<3,5$ $\mathrm{g} / \mathrm{dL}$ yang dinyatakan sembuh tertunda sebanyak 5 sampel dan sampel yang dinyatakan sembuh sebanyak 1 sampel. Sedangkan jumlah sampel dengan kadar albumin serum antara $3,5-5,5 \mathrm{~g} / \mathrm{dL}$ yang 
dinyatakan sembuh yaitu sebanyak 3 sampel. Artinya, seluruh sampel dengan kadar albumin serum antara 3,5-5,5 $\mathrm{g} / \mathrm{dL}$ dinyatakan sembuh. Terdapat hubungan yang signifikan antara kadar albumin terhadap penyembuhan luka pada pasien postoperasi laparotomi [7]. Pada penelitian lain menyatakan bahwa terdapat hubungan yang bermakna antara kadar albumin serum dengan lamanya penyembuhan luka operasi [8].

Albumin berperan dalam mempercepat proses inflamasi sehingga proses perbaikan jaringan akan berlangsung lebih cepat. Selain itu albumin juga berperan dalam mempercepat proses inflamasi sehingga proses perbaikan jaringan akan berlangsung lebih cepat. Fungsi lain dari albumin yakni menstimulasi pertumbuhan sel baru guna perbaikan jaringan [9]. Albumin memacu proses metabolisme seluler dan penting untuk pertumbuhan serta pematangan sel [10].

Luka dengan sembuh tertunda dapat disebabkan karena faktor-faktor yang mempengaruhi penyembuhan luka antara lain infeksi dan nutrisi. Infeksi pada luka berhubungan dengan tingkat kontaminasi luka. Protein utama dalam plasma adalah albumin. Fungsi albumin antara lain memelihara tekanan onkotik, mengusung hormon tiroid, asam lemak, bilirubin, obat-obatan dan sebagai protein radang fase akut, sebagai respon kekebalan tubuh terhadap infeksi, sehingga albumin berperanan penting dalam proses penyembuhan luka. Albumin berperan dalam pembentukan jaringan sel baru serta pemulihan jaringan tubuh yang rusak. Kadar albumin yang rendah memperlambat respon kekebalan tubuh dalam menghadapi infeksi sehingga proses penyembuhan luka menjadi terlambat. Oleh karena itu, nutrisi yang tidak adekuat akan memperlambat proses penyembuhan luka operasi yang tidak adekuat akan memperlambat proses penyembuhan luka operasi [11].

\section{Simpulan dan Saran}

Berdasarkan penelitian dapat disimpulkan bahwa terdapat pengaruh antara kadar albumin serum dengan penyembuhan luka pada pasien pascaoperasi laprotomi dan lumbotomi di RSD dr. Soebandi Jember dengan kekuatan korelasi kuat. Artinya, semakin tinggi kadar albumin serum, maka semakin cepat penyembuhan luka pada pasien pascaoperasi laparotomi dan lumbotomi di RSD dr. Soebandi.

Diharapkan pada penelitian selanjutnya dilakukan meta analisis atas hasil-hasil penelitian yang telah ada di Indonesia dengan populasi yang lebih besar agar didapatkan data yang lebih baik, penelitian lebih lanjut dengan waktu penelitian yang lebih lama agar mendapatkan populasi yang lebih besar, dan perlunya peran dari ahli gizi untuk memberikan informasi yang lebih luas mengenai peran albumin terhadap penyembuhan luka yang dapat ditingkatkan dengan pemenuhan asupan nutrisi yang lebih baik.

\section{Daftar Pustaka}

[1] Hidayat AA. Kebutuhan Dasar Manusia. Jakarta: Salemba Medika; 2006.

[2] Riou JP, Cohen JR, Johnson H. Factors influencing wound dehiscence. Am J Surg.; 163:324.

[3] Murray RK. Biokimia Harper. Jakarta: EGC; 2009.

[4] Sjamsuhidajat. Buku Ajar IImu Bedah. Jakarta: EGC; 2010.

[5] Smeltzer SC. Buku Ajar Keperawatan Medikal Bedah. Jakarta: EGC; 2002.

[6] Haigh E. Kamus Ringkas Kedokteran Stedman Untuk Profesi Kesehatan. Ed. 4. Jakarta: EGC; 2014.

[7] Murtutik L, Marjiyanto. Hubungan Kadar Albumin Dengan Penyembuhan Luka Pada Pasien Post Operasi Laparotomy Di Ruang Mawar Rumah Sakit Slamet Riyadi Surakarta. Jurnal IImu Keperawatan Indonesia. Surakarta: Fakultas IImu Keperawatan Universitas Sebelas Maret; 2013. Vol. 6 (3): 2-5.

[8] Agung $M$, Hendro W. Pengaruh Kadar Albumin Serum Terhadap Lamanya Penyembuhan Luka Operasi. Artikel Penelitian. Yogyakarta: Fakultas Kedokteran Universitas Gadjah Mada; 2005. Vol.18 (1): 2-4.

[9] Diah A, Choirul M, Syalfinaf M, Endang W, Winarni. Biologi 2. Jakarta: Erlangga; 2004.

[10] Tjay TH, Kirana R. Obat-obat Penting: Khasiat, Penggunaan, dan Efek-efek Sampingnya. Ed.4. Jakarta: Gramedia; 2007.

[11] Salasia, Oktavia SI, Hariono B. Patologi Klinik: Kasus Patologi Klinis. Yogyakarta: Samudra Biru; 2010. 